ISSN 0258-7122

Bangladesh J. Agril. Res. 33(3) : 587-595, December 2008

\title{
PROFITABILITY LEVEL OF MUNGBEAN CULTIVATION IN SOME SELECTED SITES OF BANGLADESH
}

\author{
Q. M. SHAFIQUL ISLAM ${ }^{1}$, M.A. MONAYEM MiAH ${ }^{2}$, \\ Q. M. ALAM ${ }^{3}$ AND. S. HOSSAIN ${ }^{4}$
}

\begin{abstract}
The study was conducted at Barisal and Jhalokati districts during 2007 to estimate the profitability and resource use efficiency of rnungbean production. The study was confined to randomly selected 100 mungbean farmers. It revealed that mungbean production is profitable to the farmers. The productivity of munghean at farm level was $928 \mathrm{~kg} / \mathrm{ha}$, which vas higher than national average of $680 \mathrm{~kg} / \mathrm{ha}$. Mungbean farmers received Tk. 24236 as gross margin per hectare. The net benefit received per kilogram of mungbean was Tk. 26.45. Benefit cost ratios were estimated at 2.53 and 3.56 on variable and cash cost basis. Functional analysis showed that human labour, urea and insecticides had positive significant contribution to mungbean cultivation. Mungbean farmers encountered various problems like untimely rainfall, lack of quality seed and disease and insect infestation, and needs immediate attention to reduce these problems.
\end{abstract}

Key Words: Profitability, mungbean, resource use efficiency.

\section{Introduction}

Pulses are the most important protein in the diet of the majority of the people in Bangladesh. It contains about twice as much protein as cereals. It also contains amino acid lysine, which is generally deficit in food grains (Elias, 1986). Pulse bran is also used as quality feed for animals. Apart from these, the ability to fix nitrogen and addition of organic matter to the soil are important factors in maintaining soil fertility (Senanayake et al., 1987; Zapata et al., 1987). Pulse fits well in the existing cropping systems, due to its short duration, low input, minimum care required and drought tolerant nature. A large number of pulse crops are grown in Bangladesh in respect of area and production (BBS. 2004).

Mungbean (Vigna radiata) is one of the most important pulse crops in Bangladesh in both area and production. Much area of mungbean is planted to cereals (Abedin. et al., 1991). Now a days, it is cultivated after harvesting of Rabi crops (i.e., wheat mustard, lentil, etc.). Due to its short duration, mungbean can fit in as a cash crop between major cropping seasons. The national statistics

\footnotetext{
${ }^{1 \& 2}$ Senior Scientific Officer, Agricultural Economics Division, BARI, Joydebpur, ${ }^{3}$ Chief Scientific Officer, Agricultural Economics Division, BARI, Joydebpur, ${ }^{4}$ Senior Scientific Officer (T\&C) Wing, BARI, Joydebpur, Bangladesh.
} 
of mungbean shows fluctuating trend in area and production and registered increasing trend in productivity due to introduction of HYV mungbean (see Appendix Table 1). It is grown three seasons a year covering 43,680 ha with an average yield of $0.68 \mathrm{t} / \mathrm{ha}$ (BBS, 2004). It provides grain for human consumption and the plants fix nitrogen addition of organic matter to the soil. It supplies a substantial amount of nitrogen to the succeeding non-legume crops (i.e., rice) grown in rotation (Sharma and Prasad, 1999). Six varieties of mungbean have been developed and disseminated with the package of management technologies to the farmers' for cultivation. Therefore, mungbean cultivation is gaining popularity day after day among the farmers. Limited study was done on mungbean in Bangladesh. For this reason, the present stud was undertaken to:

(i) know farmers' practice to grow mungbean;

(ii) know the productivity and profitability of mungbean cultivation at farm level;

(iii) examine the resource use efficiency in mungbean production; and

(iv) identify the constraints to mungbean cultivation in Bangladesh.

\section{Methodology}

The study vas conducted in two districts, namely Barisal and Jhalokati during April 2007. Uzirpur Upuzilu from Barisal district and Sadar Upuzilu from Jhalokati district were purposively selected for the study. A total of 100 mungbean farmers taking 50 farmers from each Upuzilu were randomly selected with the help of DAE personnel for interview. The crop season under the study was late ruhi (January-May). Field investigators under the direct supervision of the researchers collected field level cross sectional data using pre-tested interview schedule.

Collected data were edited, summarized, tabulated and analyzed to fulfill the objectives of the study. Tabular method of analysis using different statistical tools was used in presenting the results of the study. Profitability of mungbean production was examined on the basis of gross margin, net return and benefit cost analysis. Cobb-Douglas function was used to estimate the contribution of factors to mungbean yield. The analysis did not consider different fixed costs like rental value of land, depreciation on farm equipment, etc. as gross margin worked out in this paper. Besides, the opportunity cost of family supplied labour was taken into consideration in estimating total cost or full cost. In calculating gross margin, all operating costs vvere considered as variable cost.

\section{Analytical Model}

The production of mungbean is likely to be influenced by different factors, such as human labour, seed, chemical fertilizer, insecticide, etc. The following Cobb- 
Douglas type production function was used to estimate the parameters. The functional form of the Cobb- Douglas multiple regression equation was as follows:

$\mathrm{Y}=\mathrm{AX}_{1}{ }^{\mathrm{b} 1} \mathrm{X}_{2} \mathrm{~b}^{2}$ $X_{n}{ }^{\text {bn }} e^{u i}$

The production function was converted to logarithmic form so that it could be solved by least square method i.e.

$\log \mathrm{Y}=\log \mathrm{a}+\mathrm{b}_{1} \log \mathrm{X}_{1}+$ $+b_{n} \log X_{n}+e^{u i}$

The empirical production function was the following:

$\log Y=\log +b_{1} \log X_{1}+b_{2} \quad \log X_{2}+b_{3} \log X_{3}+b_{4} \quad \log X_{4}+b_{5} \quad \log X_{5}+b_{6}$ $\log \mathrm{X}_{6}+\mathrm{Ui}$.

Where, $Y=$ Yield $(\mathrm{kg} / \mathrm{ha})$

$\mathrm{X}_{1}=$ No. of human labour (man-day/ha)

$\mathrm{X}_{2}=$ Amount of seed $(\mathrm{kg} / \mathrm{ha})$

$\mathrm{X}_{3}$ - Amount of urea $(\mathrm{kg} / \mathrm{ha})$

$\mathrm{X}_{4}$ Amount of TSP (kg/ha)

$\mathrm{X}_{5}=$ Amount of MP $(\mathrm{kg} / \mathrm{ha})$

$\mathrm{X}_{6}=$ Cost of insecticides (Tklha)

$\mathrm{a}=$ constant value

$b_{1} b_{2} \ldots \ldots \ldots \ldots . . . . . b_{6}=$ Co-efficient of the respective variables and

$\mathrm{U}_{\mathrm{i}}=$ E.rror term.

The efficiency of inputs used in mungbean production was measured by the filiowing equation:

$\frac{M V P_{x}}{M F C_{x}}=1$ Where, MVP is the rnarginal value product of $x$ input and MFC is the marginal factor cost of $\mathrm{x}$ input. When the ratio of MVP and MFC is equal to unity indicates that the resource is efficiently used. When, the ratio is more than unity impling the resource is under utilized. In that case, there are ample opportunity to increase total production by increasing the use of specific input in the production process keeping other resources constant. When, the ratio is less than unity implying the resource is over used. In that case, it is possible to reduce production cost remains total production unchanged by decreasing the use of specific input.

\section{Results and Discussion}

\section{Agronomic practices}

The farmers prepared their land using country plough 0.90 nos. of ploughing and by power tiller 2.12 nos. of ploughing (Table 1). It was observed that the farmers 
of Barisal used higher number of power tiller. It was also observed that $60 \%$ farmers completed their sowing within the month of January. Sowing period ranged from $2^{\text {nd }}$ week of January to 3rd week of February. All the farmers followed broadcast method for seed sowing. On an average, 52\% farmers weeded their land once during vegetative growth period. Weeding was found more (67\%) in Barisal than Jhalokati (37\%). Seventy two percent farmers were found to apply insecticides to their crops, which is identical in both the areas. After picking the pod, all the farmers threshed their crops by hand beating.

Table 1 Agronomic practices of mungbean cultivation in the study areas.

\begin{tabular}{l|l|l|l}
\hline \multicolumn{1}{c|}{ Components name } & \multicolumn{1}{c}{ Barisal } & Jhalokati & All \\
\hline No. of ploughings & \multicolumn{3}{|}{} \\
$\quad$ Country plough & 0.50 & 1.03 & 0.90 \\
$\quad$ Power tiller & 2.27 & 1.97 & 2.12 \\
No. of laddering & 1.03 & 2.07 & 1.55 \\
Time of sowing (\%): & & & \\
$\quad$ Within Januar & 47 & 70 & 60 \\
$\quad$ Within February & 53 & 30 & 40 \\
Insecticide use (\%) & 70 & 73 & 72 \\
Weeding (\%) & 67 & 37 & 52 \\
\hline
\end{tabular}

\section{Pattern of input use}

The pattern of input use is shown in Table 2. Irrespective of area, a rnungbean farmer used 47 man-days of human labour per hectare of which $72 \%$ were family supplied and the rest vere hired. Barisal farmers used higher human labour (50/ha) compared to Jhalokati farmers (45/ha) due to more labour used in manuring and weeding. In most cases, power tiller was used for land preparation. A few farmers were also found to use country plough for land preparation. On an average, $24 \mathrm{~kg}$ of improved seed was used per hectare, which was more or less same for both areas. The farmers mostly used purchased seed (71\%). Farmers used BARImung-2, BARImung-5 and BINAmung- 5 varieties of mungbean. The sample farmers applied 1.6 tons of home supplied manures. The farmers of Barisal used higher amount of manures than that of Jhalokati farmers. They used chemical fertilizers like urea, TSP and MP at the rate of $27 \mathrm{~kg}, 25 \mathrm{~kg}$ and $15 \mathrm{~kg}$ per hectare, respectively, which were much lower than the recommended doses of urea $40 \mathrm{~kg} / \mathrm{ha}$, TSP $100 \mathrm{~kg} / \mathrm{ha}$ and MP $55 \mathrm{~kg} / \mathrm{ha}$. Barisal farmers used higher amount of fertilizers except DAP. Majority of the sample farmers applied insecticides, but a small number of farmers used irrigation during cultivation of rnunghean. 
Table 2. Level of input use per hectare for mungbean cultivation in the study areas.

\begin{tabular}{cllll}
\hline \multicolumn{1}{c|}{ Type of input } & Barisal & Jhalokati & All \\
\hline Human labour (man-days): & 50 & 45 & 47 \\
Own & 38 & 30 & $34(72)$ \\
Hired & 12 & 15 & $13(28)$ \\
Seed (kg) & 25 & 23 & 24 \\
Own & 11 & 4 & $7(29)$ \\
Purchased & 14 & 19 & $17(71)$ \\
Manures (kg) & 2970 & 238 & 1604 \\
Fertilizers (kg): & & & \\
Urea & 28 & 26 & 27 \\
TSP & 36 & 14 & 25 \\
MP & 22 & 7 & 15 \\
DAP & 2 & 17 & 9 \\
Irrigation (Tk) & 124 & 122 & 123 \\
Insecticides (Tk) & 477 & 517 & 497 \\
\hline
\end{tabular}

Note: Figures wIthin parentheses are the percent of total

\section{Cost of production}

The cost of production included different variable cost items like human labour, power tdler, seed, manure, fertilizer, insecticide, irrigation, etc. Both cash expenditure and imputed value of family supplied inputs ere included in the analysis and shown in Table 3. It revealed that the highest cost was incurred for crop harvesting (35.8\% of the total cost) followed by labour (23.6\%) and land preparation (16.4\%). When family supplied inputs were valued at market rate, the average cost of production in full cost basis was found to be Tk. 16004/ha. The slightly higher cost of production was found in Barisal (Tk. 16,336/ha) compared to Jhaiokati due to higher mandays labour, manures and fertilizers. Average land preparation cost was Tk. 2622/ha and it was more in Jhalokati due to more ploughings and ladderings. Higher cost was incurred for manures and fertilizers in Barisal areas. 
Table 3. Cost of mungbean cultivation by the sample farmers in the study areas.

\begin{tabular}{lllll}
\hline \multicolumn{1}{c}{ Type of input } & \multicolumn{1}{r}{ Barisal } & \multicolumn{1}{c}{ Jhalokati } & \multicolumn{1}{c}{ All } \\
\hline Land preparation & $2381(14.6)$ & $2865(18.3)$ & $2622(16.4)$ \\
Own & 215 & 724 & 469 \\
Hired & 2166 & 2141 & 2153 \\
Human labour (man-days) & $4021(24.6)$ & $3544(22.6)$ & $3783(23.6)$ \\
Own & 3067 & 2376 & 2721 \\
Hired & 954 & 1168 & 1061 \\
Seed & $1223(7.5)$ & $1292(8.2)$ & $1258(7.9)$ \\
Own & 538 & 199 & 368 \\
Purchased & 686 & 1093 & 890 \\
Manures & $1114(6.4)$ & $89(0.6)$ & $601(3.8)$ \\
Fertilizers & $1107(6.8)$ & $776(5.0)$ & $941(5.9)$ \\
Urea & 196 & 168 & 182 \\
TSP & 574 & 280 & 427 \\
MP & 317 & 155 & 236 \\
DAP & 20 & 173 & 96 \\
Irrigation & $124(0.8)$ & $122(0.8)$ & $123(0.8)$ \\
Insecticides & $477(2.9)$ & $517(3.3)$ & $497(3.1)$ \\
Crop harvesting & $5450(33.4)$ & $5996(38.3)$ & $5723(35.8)$ \\
Int. on operating capital* & $439(2.7)$ & $473(3.0)$ & $456(2.8)$ \\
Total variable cost & $16336(100)$ & $15674(100)$ & $16004(100)$ \\
Total cash cost & 10964 & 11813 & 11388 \\
\hline
\end{tabular}

*Note. assumed $8 \%$ interest rate for 6 months

\section{Productivity and profitability of mungbean}

The sample farmers received, on an average, $928 \mathrm{~kg} / \mathrm{ha}$ of rnungbean, which was higher than the national average of $771 \mathrm{~kg} / \mathrm{ha}$ (BBS, 2004). The productivity of rnungbean found in Barisal and Jhalokati were mostly similar to the average yield (Table 4).

Table 4. Profitability of mungbean cultivation in the study areas.

\begin{tabular}{|c|c|c|c|}
\hline Type of input & Barisal & Jhalokati & All \\
\hline 1. Yield (kg/ha) & 933 & 924 & 928 \\
\hline 2. Gross return (Tk/ha) & 40572 & 40531 & 40552 \\
\hline \multicolumn{4}{|l|}{ 3. Total cost $(\mathrm{Tk} / \mathrm{ha})$ : } \\
\hline Total cash cost & 10964 & 11813 & 11388 \\
\hline Total variable cost & 16336 & 15676 & 16003 \\
\hline 4. Gross margin (Tk/ha) & 24236 & 24857 & 24549 \\
\hline \multicolumn{4}{|l|}{ 5. Benefit cost ratio: } \\
\hline Cash cost basis & 3.70 & 3.43 & 3.56 \\
\hline Variable cost basis & 2.48 & 2.59 & 2.53 \\
\hline \multicolumn{4}{|l|}{ 6. Cost of grain $(\mathrm{Tk} / \mathrm{kg})$ : } \\
\hline Cash cost basis & 11.75 & 12.78 & 12.27 \\
\hline Variable cost basis & 17.51 & 16.96 & 17.24 \\
\hline 7. Benefit from grain $(\mathrm{Tk} / \mathrm{kg})$ & 25.98 & 26.90 & 26.45 \\
\hline
\end{tabular}


The average gross return from rnungbean production was found to be Tk. 40552/ha and gross margin on full cost basis Tk. 24,549/ha. The benefit cost ratios was estimated at 3.56 on cash cost basis and 2.53 on full cost basis, implying that one taka investment in munghcan production sould generate Tk.3.56 and Tk. 2.53, respectively. The cost of grain vas Tk. 12.27 on cash cost basis and Tk 17.24 on full cost basis. Benefit from per kilogram rnunghean production was Tk. 26.45.

\section{Factors affecting and resource use efficiency in mungbean production}

The coefficient of adjusted $\mathrm{R}$ is 0.806 implying that the explanatory variables included in the model explained $81 \%$ variation in the yield of rnungbean. The F-value of the equation is significant at 100 level implying that the variation in yield of rnungbean depends mainly upon the explanatory variables included in the model. The contribution of specified factors affecting production of rnungbean can be seen from the estimation of regression equation (Table 5). Vary few farmers used manure and irrigation, so this was not include in the equation. The result showed that only one coefficient does not have the expected sign. However, the coefficients for human labour, seed and urea were found to be positively significant at $1 \%, 5 \%$ and $5 \%$ level, respectively. The positive sign indicated that using more of these three inputs in rnungbean production could increase yield to some extent. The estimated coefficients revealed that $1 \%$ increase in the amount of human labour, seed and urea keeping all other factors constant, would uplift the yield of rnungbean by 0.445 , 0.371 and $0.022 \%$, respectively. On the other hand, the coefficient of TSP is negatively significant at $10 \%$ level, implying that $1 \%$ increase in the amount of TSP keeping all other factors constant, would decrease the yield of mungbean by $0.01 \%$ (Table 5 ).

Table 5 also shows that the ratios of MVP and MFC for labour, seed and urea are greater than one and positive indicating inefficient use of these inputs. Therefore, the farmers in the study areas had potentially ample opportunities to increase mungbean production by using more of these inputs. On the other hand, the ratios are less than one and negative and positily respective for TSP and MP implying an inefficient use of these inputs. In these cases, the farmers can easily decrease production cost, keeping mungbean production constant, by decreasing the use of TSP and MP. 
Table 5. Estimated values of coefficients and related statistics of Cobb-Douglas production function model.

\begin{tabular}{l|l|l|l|l}
\hline \multirow{2}{*}{ Item } & \multicolumn{2}{l}{ All areas } & \multirow{2}{*}{ MVII MFC } \\
\cline { 2 - 4 } & Coefficient & t-value & P-value & \\
\hline Intercept & $3.809^{* * *}$ & Il .332 & 0.0000 & \\
Human labour $(\mathrm{Xi})$ & $0.445^{* * *}$ & 6.071 & 0.0000 & 4.77 \\
Seed( $\left.\mathrm{X}_{2}\right)$ & $0.371^{* *}$ & 2.147 & 0.0362 & 11.96 \\
Urea $\left(\mathrm{X}_{3}\right)$ & $0.022^{* *}$ & 2.394 & 0.0201 & 4.90 \\
TSP $\left(\mathrm{X}_{4}\right)$ & $0.014^{*}$ & -1.718 & 0.0913 & -1.33 \\
MP $\left(\mathrm{X}_{5}\right)$ & 0.005 & 0.744 & 0.4595 & 0.86 \\
\hline Adjusted $\mathrm{R}^{2}$ & 0.806 & & & \\
F-value & $50.035^{* * *}$ & & & \\
\hline
\end{tabular}

Note: '*' '**' and '***' indicate significant at $10 \% .5 \%$ and $1 \%$ level.

\section{Constraints to mungbean production}

The sample farmers encountered different constraints to cultivating rnungbean. The major constraints were found to be untimely rainfall $(67 \%)$, incidence of diseases (65\%), lack of quality seed (50\%), insect infestation (15\%) and lack of suitable land for cultivation (Table 6). Farmers opined that they could not attain expected yield due to these constraints.

Table 6. Constraints to mungbean cultivation in the study areas.

\begin{tabular}{l|l|l|ll}
\hline \multirow{2}{*}{\multicolumn{1}{c}{ Items }} & \multicolumn{4}{c}{ Percent farmers' } \\
\cline { 2 - 5 } & \multicolumn{1}{c}{ Barisal } & Jhalokati & All \\
\hline Untimely rainfall & 70 & 66 & 67 & \\
Incidence of diseases & 68 & 64 & 50 & \\
Lack of quality seed & 48 & 52 & 5 & \\
Lack of suitable land & 6 & 5 & 4 & \\
Others* & 3 & 4 & & 50 \\
\hline
\end{tabular}

* Higher price of seed and fertilizers

\section{Conclusion}

It is concluded from the aforesaid discussion that the yield performance of rnungbean is higher than national average. The rnungbean production in the study areas is profitable. Munghean farmers received higher return on their investment. Analysis of resource use efficiency indicates that more profit can be obtained by increasmg investment in crop management and application of urea and insecticide for mungbean cultivation. Although munghean is a profitable crop, farmers could not harvest expected benefit due to various problems.

The quality seed of the existing improved variety should be made available to the farmer for greater extension of this crop. Nevertheless, due efforts should 
be made to develop disease free and insect tolerant variety for getting higher return from rnungbean production in near future.

\section{References}

Ahedin. M.Z. and M. Anwarul. 1991. Prospects of increasing pulse production through improved cropping systems. In: Proceedings of the 2 National Workshop on Pulses. BARI, Joydebpur, Gazipur.

BBS. 2004. Bangladesh Bureau of Statistics. Statistical Yearbook of Bangladesh. Statistics Division, Ministry of Planning, GOB.

Elias. S. M., M.S. Hossain, F.S. Sikder, Juber Ahmed and M. Rezaul Karirn. 1986. Identification of constraints to pulse production with special reference to present farming systems. Annual Report of the Agricultural Economics Diision. BARI, Joydebpur. p-I.

Senanayake., L., D.P., Knievel, S. E. Stevena, 1987. Nodulation and symbiotic nitrogen fixation of cowpea (Vigna unguiculata L.). Plant Soil 99: 435-439.

Sharma. S. N. and R. Prasad, 1999. Effects of sesbania green manuring and mungbean residue incorporation of productivity and nitrogen uptake of a rice-wheat cropping system. Bioresource Technology 67(2): 171-175.

Zapata. F., S.K.A. Danso, G. Hardarson. M. Fried, 1987. Nitrogen fixation and translocation in field-grown fababean. Agronomy Journal 79: 505-509.

Appndix table 1. Area, production and yield of mungbean in Bangladesh.

\begin{tabular}{l|l|l|c}
\hline \multicolumn{1}{c}{ Year } & Area (ha) & Production ('000'ton) & Yield (t/ha) \\
\hline $1990-91$ & 57.9 & 32.0 & 0.55 \\
$1991-92$ & 55.4 & 32.0 & 0.58 \\
$1992-93$ & 53.4 & 31.0 & 0.58 \\
$1993-94$ & 53.7 & 30.3 & 0.56 \\
$1994-95$ & 53.8 & 32.0 & 0.59 \\
$1995-96$ & 55.0 & 32.0 & 0.58 \\
$2003-04$ & 43.6 & 29.6 & 0.68 \\
\hline
\end{tabular}

Source: BBS. 2004 